\title{
The bZIP transcription factor LCR-F1 is essential for mesoderm formation in mouse development
}

\author{
Susan C. Farmer, ${ }^{1,4}$ Chiao-Wang Sun, ${ }^{1,4}$ Glenn E. Winnier, ${ }^{2}$ Brigid L.M. Hogan, ${ }^{2,3}$ and \\ Tim M. Townes ${ }^{1,5}$ \\ ${ }^{1}$ Department of Biochemistry and Molecular Genetics, Schools of Medicine and Dentistry, University of Alabama at \\ Birmingham, Birmingham, Alabama 35294 USA; $^{2}$ Department of Cell Biology and ${ }^{3}$ Howard Hughes Medical Institute, \\ Vanderbilt University Medical Center, Nashville, Tennessee 37232-2175 USA
}

\begin{abstract}
LCR-F1 is a mammalian bZIP transcription factor containing a basic amino acid domain highly homologous to a domain in the Drosophila Cap 'N' Collar and Caenorhabditis elegans SKN-1 proteins. LCR-F1 binds to AP1-like sequences in the human $\beta$-globin locus control region and activates high-level expression of $\beta$-globin genes. To assess the role of LCR-F1 in mammalian development, the mouse Lcrf1 gene was deleted in embryonic stem (ES) cells, and mice derived from these cells were mated to produce Lcrf1 null animals. Homozygous mutant embryos progressed normally to the late egg cylinder stage at $\sim 6.5$ days post coitus (dpc), but development was arrested before $7.5 \mathrm{dpc}$. Lcrf1 mutant embryos failed to form a primitive streak and lacked detectable mesoderm. These results demonstrate that LCR-F1 is essential for gastrulation in the mouse and suggest that this transcription factor controls expression of genes critical for the earliest events in mesoderm formation. Interestingly, Lcrf1 null ES cells injected into wild-type blastocysts contributed to all mesodermally derived tissues examined, including erythroid cells producing hemoglobin. These results demonstrate that the Lcrf1 mutation is not cell autonomous and suggest that LCR-F1 regulates expression of signaling molecules essential for gastrulation. The synthesis of normal hemoglobin levels in erythroid cells of chimeras derived from Lcrf1 null cells suggests that LCR-F1 is not essential for globin gene expression. LCR-F1 and the related bZIP transcription factors NF-E2 p45 and NRF2 must compensate for each other in globin gene regulation.
\end{abstract}

[Key Words: LCR-F1; mesoderm; gastrulation; knockout]

Received November 27, 1996; revised version accepted February 3, 1997.

LCR-FI (locus control region-factor $\underline{1}$ ) is a basic leucine zipper (bZIP) transcription factor that was identified in two independent screens (Chan et al. 1993; Caterina et al. 1994) for erythroid proteins that bind functionally important AP1-like sequences (also designated NF-E2 sequences) in the human $\beta$-globin LCR (for review, see Orkin 1990; Townes and Behringer 1990; Stamatoyannopoulos 1991; Dillon and Grosveld 1993; Martin et al. 1996). Deletion of these APl-like sequences inhibits virtually all of the enhancer activity of LCR DNase I hypersensitive site 2 (HS2) in cultured erythroid cells (Moi and Kan 1990; Ney et al. 1990; Talbot et al. 1990) and in transgenic mice (Caterina et al. 1991; Talbot and Grosveld 1991; Liu et al. 1992). Conservation of these AP1like sequences in $\beta$-globin LCR DNase I hypersensitive sites 2,3 , and $4(\mathrm{HS} 2,3,4)$ in humans, galagos, rabbits, goats, and mice (Hardison et al. 1994) suggests that these

${ }^{4}$ These authors contributed equally to this work.

${ }^{5}$ Corresponding author.

E-MAIL ttownes@bmg.bhs.uab.edu; FAX (205) 934-2889. sequences are also critical for LCR function in HS3 and HS4. Deletion of the AP1-like sequences in human HS4 inhibits hypersensitive site formation (Stamatoyannopoulos et al. 1995). Although LCR-F1, also designated NRF1, TCF-11, and NFE2L1 (Chan et al. 1993; Luna et al. 1994; McKie et al. 1995), is expressed ubiquitously, it activates high-level $\beta$-globin gene expression specifically in erythroid cells in transient transfection experiments (Caterina et al. 1994).

LCR-F1 contains a 30-amino-acid basic domain that is $70 \%$ homologous to a domain in the Drosophila melanogaster Cap'N'Collar (CNC) protein (Mohler et al. $1991,1995)$ and $65 \%$ homologous to a domain in the Caenorhabditis elegans SKN-1 protein (Bowerman et al. 1992, 1993). Both CNC and SKN-1 play important roles in development. CNC is expressed during Drosophila gastrulation, and a null mutation in this gene is embryonic lethal (Mohler et al. 1991, 1995). cnc mutant embryos initiate gastrulation but are unable to form complete head structures. SKN-1 is a maternally expressed protein that is asymmetrically distributed in C. elegans 
embryos at the two-cell stage (Bowerman et al. 1992, 1993). This transcription factor interacts with at least one other protein, POP-1, to specify a progenitor cell designated MS at the four cell stage (Lin et al. 1995). This mesodermal precursor produces predominately pharynx and body wall muscle. In $S k n 1$ mutants, MS produces hypodermal cells and muscle, demonstrating that MS cell fate is altered.

To assess the role of LCR-F1 in mouse development, we inactivated the gene by homologous recombination in embryonic stem (ES) cells. Lcrf1 null $(-/-)$ embryos developed to the late egg cylinder stage with no apparent growth retardation, but development was arrested $\sim 6.5$ days postcoitus (dpc). Lcrf1 null embryos failed to form a primitive streak and were unable to produce mesoderm. These results demonstrate that LCR-F1 is essential for gastrulation in the mouse and suggest that this transcription factor controls expression of genes critical for the earliest events in mesoderm formation.

\section{Results \\ Generation of an Lcrf1 mutant allele in the mouse germ line}

To mutate the Lcrf1 gene in mouse ES cells, we constructed a targeting vector (Fig. 1A) in which $3.5 \mathrm{~kb}$ of genomic $L c r f 1$ sequence was replaced by a $\mathrm{PGKneo}^{\mathrm{r}}$ cassette. This deletion removed all of coding exons $3 \mathrm{~A}, 3 \mathrm{~B}$, 4 , and 5 , as well as most of the coding region of exon 6 ; therefore, all known functionally important domains of the protein $(\mathrm{HOB}, \mathrm{CNC}$, bZIP, putative nuclear localization signal, and transcriptional activation domains) were deleted. Cells containing the correctly targeted allele, designated $L c r f 1^{\text {tm1 1uab }}$, were identified by Southern blot hybridization (data not shown) and injected into 3.5-day blastocysts from C57BL/6 mice to produce chimeras. Chimeric males were mated to Black Swiss outbred females, and agouti offspring heterozygous for the mutation were identified by Southern blot hybridization or PCR analysis of tail DNA (Fig. 1B,C). The mutant allele produced a $39-\mathrm{kb} \mathrm{KpnI}$ fragment and a 4.6-kb BamHI fragment when blots were hybridized with $5^{\prime}$ and $3^{\prime}$ probes, respectively. A single 4.6-kb BamHI fragment was detected with a probe to the neomycin resistance cassette; this result verified that additional, random integrants of the targeting vector did not occur.

\section{The Lcrf1 null mutation is embryonic lethal}

Heterozygous $L c r f 1^{\text {tm1uab }}$ mice appeared normal and were fertile. When heterozygous males and females were mated, no homozygous mutant offspring were obtained in 195 progeny (Table 1); Figure 1C illustrates PCR analysis of a typical litter. These results suggested that the null mutation was embryonic lethal. Preliminary results also suggest that the null mutation is embryonic lethal on C57BL/6, CD1, and 129/Sv backgrounds (data not shown).

To determine the stage of embryonic death, embryos obtained from timed matings between heterozygotes were genotyped by PCR or in situ hybridization. No homozygous mutant embryos were observed at 9.5 or 8.5 dpc by PCR analysis (Table 1), and the percentage of empty decidua at these times was unusually high $119 \%$; Table 2). At $7.5 \mathrm{dpc}, 6 \%$ of the embryos isolated were $-/-$ by PCR. This number is significantly below the percentage expected by Mendelian segregation (25\%), suggesting that the majority of mutant embryos died before this stage. In addition, $20 \%$ of the 7.5 -dpc decidua analyzed appeared empty. Histological sections of 7.5-dpc decidua produced from matings between heterozygotes indicated that these empty decidua contained reabsorbing embryos. A typical resorption site and normal control are illustrated in Figure 2.

To further characterize the stage of embryonic lethality, sections of 6.5-dpc embryos were genotyped by in situ hybridization with an Lcrf1 exon 6 probe (Fig. 3). Probe sequences were absent in homozygous mutants; therefore, this probe distinguished $+1+$ and $+/-$ from $-/-$ embryos. Lcrf1 RNA was detected in all three germ layers and in extraembryonic ectoderm and mesoderm in $64 \%$ of the embryos examined; no RNA was detected in $36 \%$ of the embryos (Table 1). This percentage of homozygous mutants $(36 \%)$ is in the range expected for normal segregation $(25 \%)$. In addition, the percentage of empty decidua at 6.5 dpc was only $8 \%$ (Table 2 ), which is similar to the number observed in matings between wild-type animals (Deng et al. 1994; Stephens et al. 1995; Winnier et al. 1995). These results demonstrate that the majority of $L c r f 1^{\text {tm1uab }}$ mutant embryos die between 6.5 and $7.5 \mathrm{dpc}$.

No mesoderm formation is morphologically detectable in Lcrf1 null embryos

Histological sections of 6.5-dpc embryos produced from matings between heterozygotes were examined to determine the possible cause of embryonic death. Normal layers of embryonic ectoderm, mesoderm, and endoderm were clearly distinguishable in embryos that were Lcrf1 positive $(+/+$ or $+/-)$ by in situ hybridization (Fig. 3A,B). However, no mesodermal layer (embryonic or extraembryonic) was observed in homozygous $L c r f 1^{\text {tm1uab }} \mathrm{em}$ bryos (Fig. 3C,D), although embryonic ectoderm and visceral endoderm layers appeared normal. The Lcrf1 null embryos formed normal egg cylinders indistinguishable from wild type. However, no primitive streak was initiated, and mesoderm formation was absent. These results strongly suggest that LCR-F1 is essential for one of the earliest steps in mammalian mesoderm formation.

To determine whether Lcrf1 expression is regulated developmentally in the early mouse embryo, we analyzed RNA from undifferentiated ES cells and blastocysts. RT-PCR analysis (Fig. 4) demonstrates that Lcrf1 mRNA is absent in wild-type, undifferentiated ES cells (lane 1) and 3.5-day-old mouse blastocysts (lane 2). However, high-level expression is observed in 6.5-day-old embryos (Figs. 3A,B) and in 8.0-day-old embryoid bodies derived from differentiated, Lcrf1 +/- ES cells (Fig. 4, lane 


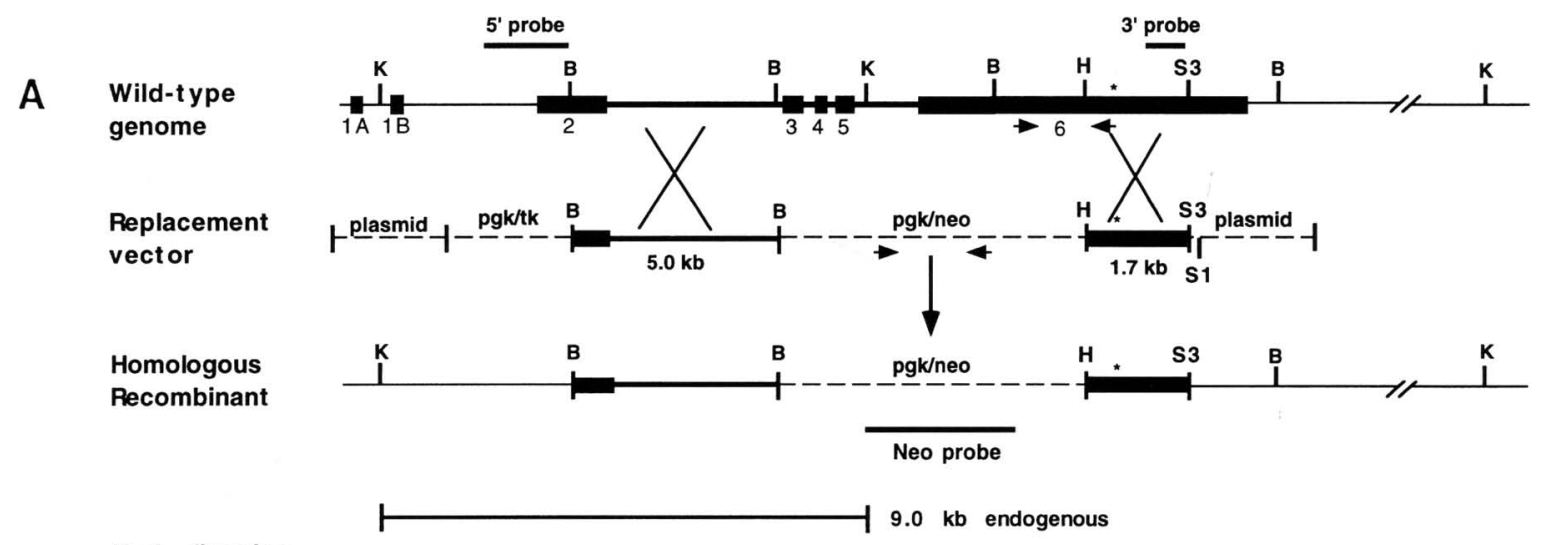

Kpnl digestion

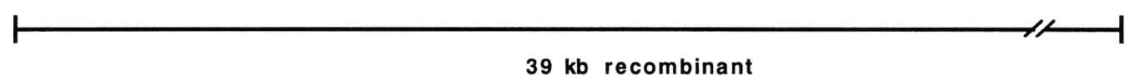

BamHI digestion

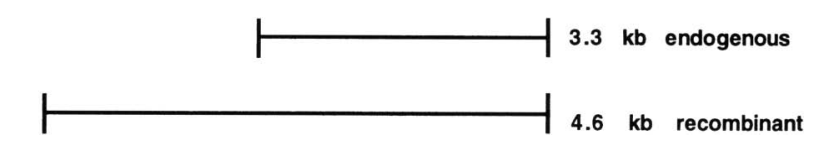

$\begin{array}{lccc}\text { B Enzyme: } & \text { Kpn I } & \text { Bam HI } & \text { BamHI } \\ \text { Probe: } & 5, & 3^{\prime} & \text { Neo }\end{array}$
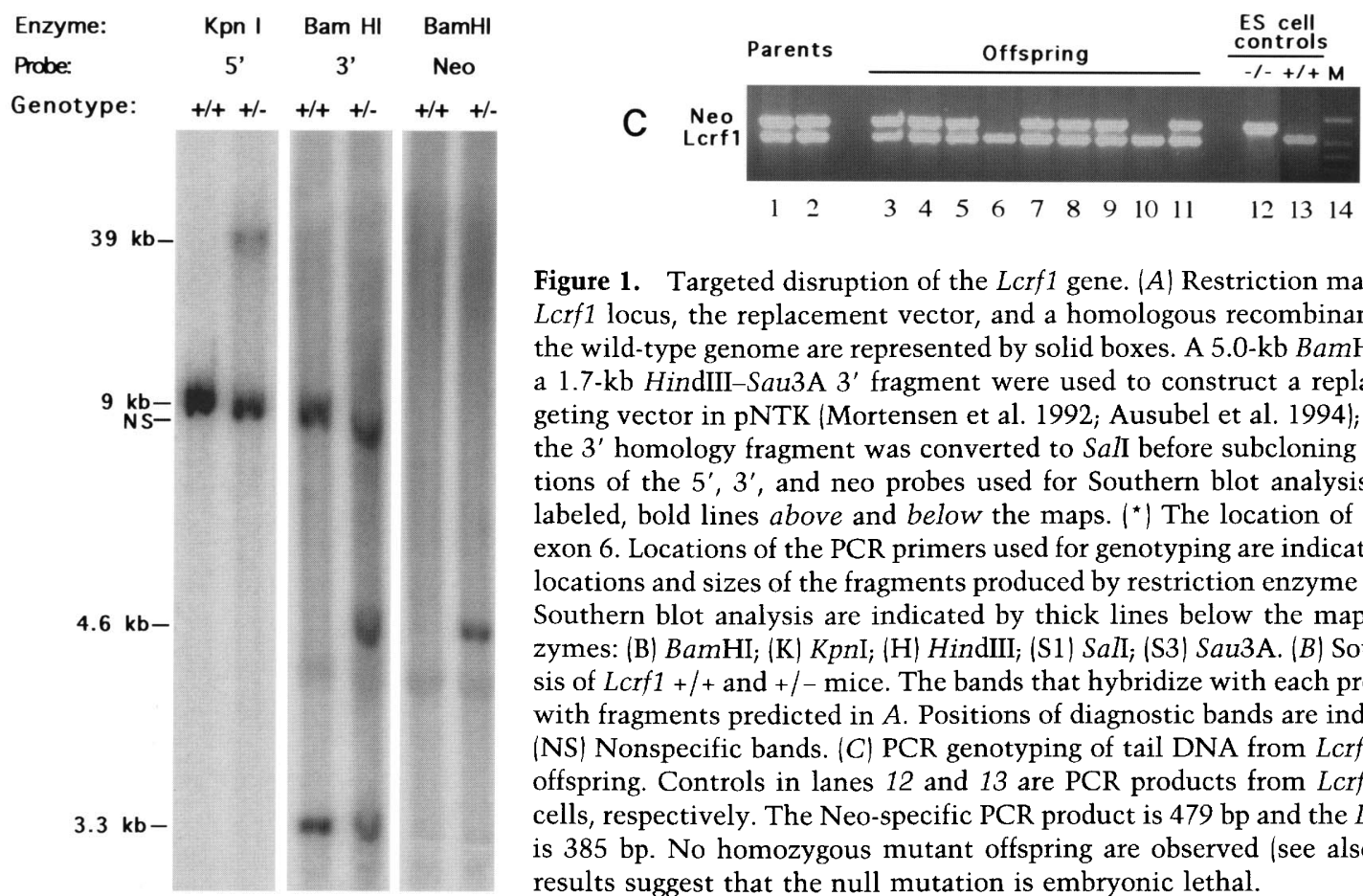

Figure 1. Targeted disruption of the Lcrf1 gene. (A) Restriction map of the wild-type Lcrf1 locus, the replacement vector, and a homologous recombinant allele. Exons in the wild-type genome are represented by solid boxes. A 5.0-kb BamHI 5' fragment and a 1.7-kb HindIII-Sau3A 3' fragment were used to construct a replacement gene targeting vector in pNTK (Mortensen et al. 1992; Ausubel et al. 1994); the Sau3A site in the $3^{\prime}$ homology fragment was converted to SalI before subcloning into pNTK. Locations of the $5^{\prime}, 3^{\prime}$, and neo probes used for Southern blot analysis are indicated by labeled, bold lines above and below the maps. $\left(^{*}\right)$ The location of the stop codon in exon 6. Locations of the PCR primers used for genotyping are indicated by arrows. The locations and sizes of the fragments produced by restriction enzyme digestions used in Southern blot analysis are indicated by thick lines below the maps. Restriction enzymes: (B) BamHI; (K) KpnI; (H) HindIII; (S1) SalI; (S3) Sau3A. (B) Southern blot analysis of $L c r f 1+/+$ and $+/-$ mice. The bands that hybridize with each probe are consistent with fragments predicted in $A$. Positions of diagnostic bands are indicated on the left. (NS) Nonspecific bands. (C) PCR genotyping of tail DNA from $L c r f 1+/-$ parents and offspring. Controls in lanes 12 and 13 are PCR products from $L c r f 1-/-$ and $+1+$ ES cells, respectively. The Neo-specific PCR product is $479 \mathrm{bp}$ and the Lcrf1 PCR product is $385 \mathrm{bp}$. No homozygous mutant offspring are observed (see also Table 1). These results suggest that the null mutation is embryonic lethal.

3). As expected, no Lcrf1 mRNA is detected in 8.0-dayold embryoid bodies derived from differentiated, Lcrf1 -/- ES cells (Fig. 4, lane 4). The activation of high-level Lcrf1 expression between 3.5 and 6.5 days of mouse development is consistent with a key role for LCR-F1 in early development.

Brachyury expression is absent in homozygous mutant embryos

Although no morphologically distinguishable mesoderm
Table 1. Genotypes of offspring from $+/-x+1-$ matings

\begin{tabular}{lrccc}
\hline Age & Total & $+/+$ or $+/-$ & $-/-$ & $\%-/-$ \\
\hline Adult & 195 & 195 & 0 & 0 \\
$9.5 \mathrm{dpc}$ & 24 & 24 & 0 & 0 \\
$8.5 \mathrm{dpc}$ & 34 & 34 & 0 & 0 \\
$7.5 \mathrm{dpc}$ & 49 & 46 & 3 & 6 \\
$6.5 \mathrm{dpc}$ & 55 & 35 & 20 & 36 \\
\hline
\end{tabular}

Embryos were genotyped by PCR at $7.5,8.5$, and $9.5 \mathrm{dpc}$ and by in situ hybridization at $6.5 \mathrm{dpc}$ (see Materials and Methods). 
Table 2. Empty decidua from $+/-x+/-$ matings

\begin{tabular}{lccc}
\hline Age & Total & No. empty & Percent empty \\
\hline $9.5 \mathrm{dpc}$ & 31 & 6 & 19 \\
$8.5 \mathrm{dpc}$ & 62 & 12 & 19 \\
$7.5 \mathrm{dpc}$ & 137 & 27 & 20 \\
$6.5 \mathrm{dpc}$ & 196 & 15 & 8 \\
\hline
\end{tabular}

was observed in Lcrf1 null embryos, a small number of mesodermal cells could be present. To investigate this question at the molecular level, sections of $6.5-\mathrm{dpc}$ embryos were genotyped by hybridization with Lcrf1 probe as described above, and adjacent sections were analyzed by in situ hybridization with a probe for Brachyury $(T)$. This gene is normally expressed at $6.5 \mathrm{dpc}$ in the mesoderm of the primitive streak and is one of the earliest markers for mesoderm formation (Wilkinson et al. 1990; Beddington et al. 1992; Kispert and Herrmann 1994). Lcrf1-positive embryos exhibited a normal pattern of $T$ expression, as illustrated in the sagittal and transverse sections in Figure 5, A and B, respectively. However, no $T$ expression was observed in homozygous Lcrfitm1uab embryos (Fig. 5C,D). These data confirm that Lcrf1 null embryos generate no demonstrable primitive streak mesoderm.

\section{Effect of the Lcrf1 null mutation is not} cell-autonomous

To determine whether the Lcrf1 null mutation is cellautonomous, homozygous mutant (-/-) ES cells were de-
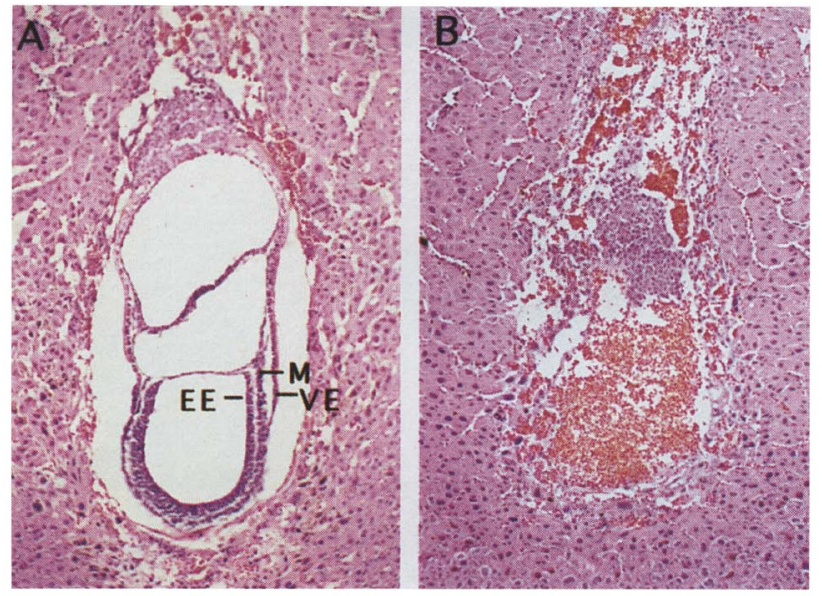

Figure 2. Histological section of $7.5 \mathrm{dpc}$ littermates from a mating between Lcrf1 heterozygous mice. At $7.5 \mathrm{dpc}$, decidua were sectioned and stained with hematoxylin/eosin. At this developmental time point, $80 \%$ of the embryos examined appeared morphologically normal $\langle A| ; 20 \%$ were reabsorbing $(B)$. Locations of the three primary germ layers in the normal embryo: (EE) embryonic ectoderm; (M) mesoderm in the primitive streak $_{i}(\mathrm{VE})$ visceral endoderm. None of these layers is distinguishable in the reabsorbing embryo in $B$.

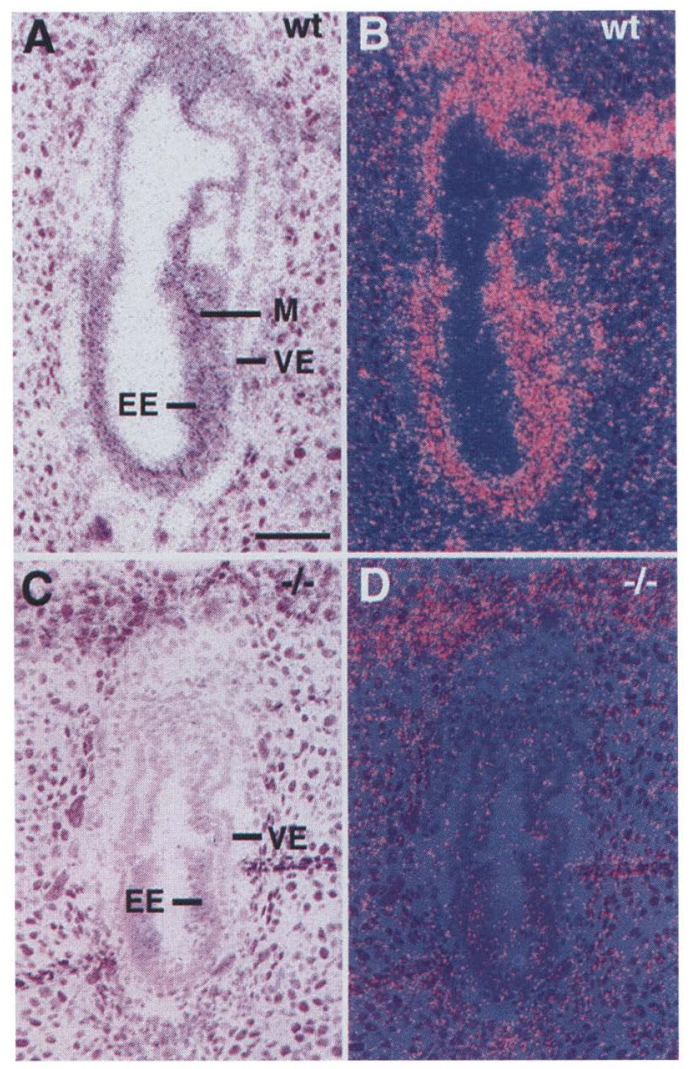

Figure 3. In situ hybridization of 6.5-day-old embryos with Lcrf1 probe. Sections of 6.5 -dpc embryos were hybridized with a probe containing $L c r f 1$ exon 6 sequences deleted in the knockout allele. $(A, B)$ An Lcrf1 positive embryo. Lcrf1 expression is ubiquitous in the embryo. No signal was detected with a sensestrand probe on other sections (data not shown). Normal egg cylinder development and early primitive streak formation are apparent. (C,D) An Lcrf1 negative embryo. No Lcrf1 expression is detected, and no mesodermal layer is observed. (EE) Embryonic ectoderm (epiblast); (VE) visceral endoderm; (M) mesoderm in the primitive streak. Scale bar in $A, 60 \mu \mathrm{m}$. All panels are the same magnification.

rived by growing $+/$ - cells in increased levels of G418 (Mortensen et al. 1992; Ausubel et al. 1994). Surviving clones were genotyped by Southern blot analysis (Fig. 6A; data not shown/, and two euploid Lcrf1 -/- lines were injected into 3.5 -dpc $\mathrm{C} 57 \mathrm{BL} / 6$ blastocysts to produce chimeras. Glucose phosphate isomerase (GPI) analysis of blood from five high level chimeras $175 \%$ to $90 \%$ based on coat color) indicated that the - / ES cells had contributed to this tissue derived from mesoderm (Fig. 6B). High-pressure liquid chromotography (HPLC) analysis of hemolysates from these chimeras detected high levels of hemoglobins characteristic of the 129/Sv mouse strain from which the ES cells are derived /data not shown). Animals with high blood contribution from the -/-ES were not anemic, and their hematological indices were not significantly different from those of nonchimeric (nonagouti) littermates (data not shown). These results demonstrate that red blood cells derived 


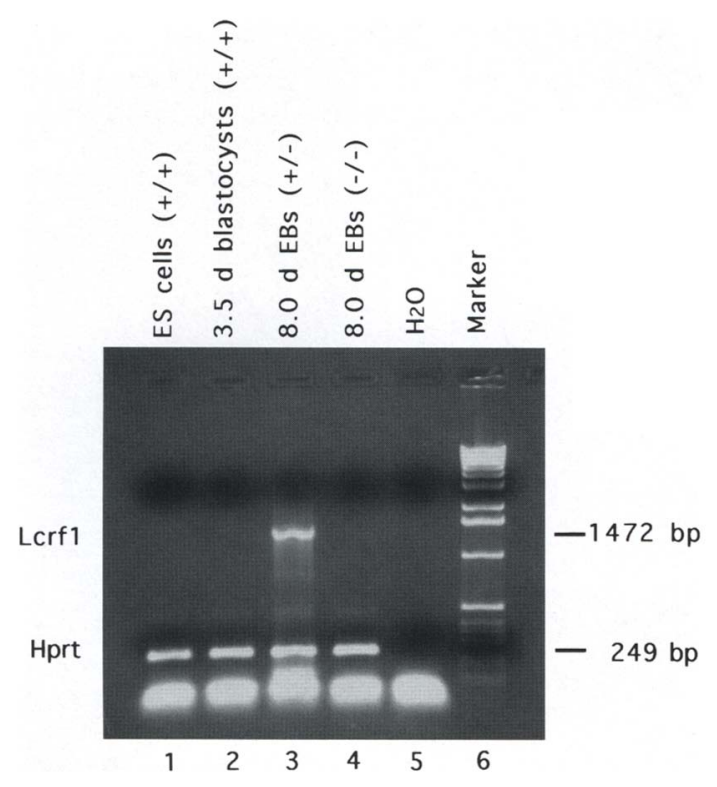

Figure 4. RT-PCR analysis of ES cells, 3.5-day-old blastocysts, and 8.0-day-old EBs. RNA prepared from ES cells, 3.5-day-old blastocysts, and 8.0-day-old EBs was reverse transcribed and amplified with Lcrf1- and Hprt-specific primers. (Lane 1) Undifferentiated, wild-type ES cells; (lane 2) wild-type 3.5-day-old blastocysts; (lane 3) 8.0-day-old embryoid bodies derived from differentiated Lcrf1 +/- ES cells; (lane 4) 8.0-day-old EBs derived from differentiated Lcrf1 -/- ES cells; (lane 5) $\mathrm{H}_{2} \mathrm{O}$ control; and (lane 6) 1-kb marker (BRL/GIBCO). The results demonstrate that Lcrf1 gene expression is regulated developmentally.

from the -/- ES cells developed normally and produced hemoglobin. GPI analysis of other mesodermally derived or mesoderm-containing tissues (kidney, liver, lung, muscle, spleen) in these chimeras also demonstrated high level contribution from the Lcrf1-/- ES cells. These results indicate that the effect of the $L c r f 1^{\text {tm1uab }}$ mutation is not cell-autonomous; $+/+$ cells derived from wild-type blastocysts can rescue the mutant phenotype at gastrulation. Therefore, LCR-F1 must control transcription of genes encoding a secreted factor or cell surface molecule essential for gastrulation. Lcrf1 -/- cells rescued by this factor contribute to many tissues derived from mesoderm, including blood.

To investigate the effect of the $\operatorname{Lcrf1} 1^{\text {tm1 } 1 \text { uab }}$ mutation on hematopoiesis and globin expression in vitro, Lcrf1 $+/$ - and -/- ES cells were differentiated in methylcellulose cultures (Wiles 1993), and the resulting embryoid bodies (EBs) were examined. A dramatic decrease in red blood cell formation and hemoglobin synthesis was observed after in vitro differentiation of -/ - ES cells (Fig. 7). Large numbers of hemoglobinized cells were found in both unstained (Fig.7A) and benzidine-stained EBs (Fig 7C) derived from +/- ES cells; however, in -/ EB cultures, only occasional hemoglobinized cells could be identified (Fig. 7B,D). When EBs were collected by centrifugation, a benzidine-stained layer of hemoglobin-producing cells was observed at the top of the pellet only in
+/- EBs (Fig. 7E). Northern blot analysis of embryoid body RNA (Fig. 7F) confirmed that globin mRNA levels were significantly reduced in -/- EB cultures. In addition, nucleated red blood cell precursors were formed in +/- EBs (Fig. 7G) but not in -/- EBs (Fig. 7H).

The simplest interpretation of the in vitro (EB) and in vivo (chimera) data is that decreased globin expression in vitro is a consequence of severely reduced or absent mesoderm formation and is not attributable to a direct effect of the Lcrf1 mutation on erythropoiesis or globin gene expression. The normal hematological values in chimeras with a high contribution from the Lcrf1 -/cells demonstrate that LCR-F1 is not essential for definitive hematopoiesis or adult globin gene expression. LCRF1 and two other CNC family members, NF-E2 p45 and NRF2, are all capable of strong transcriptional transactivation of globin gene expression in transfected erythroid

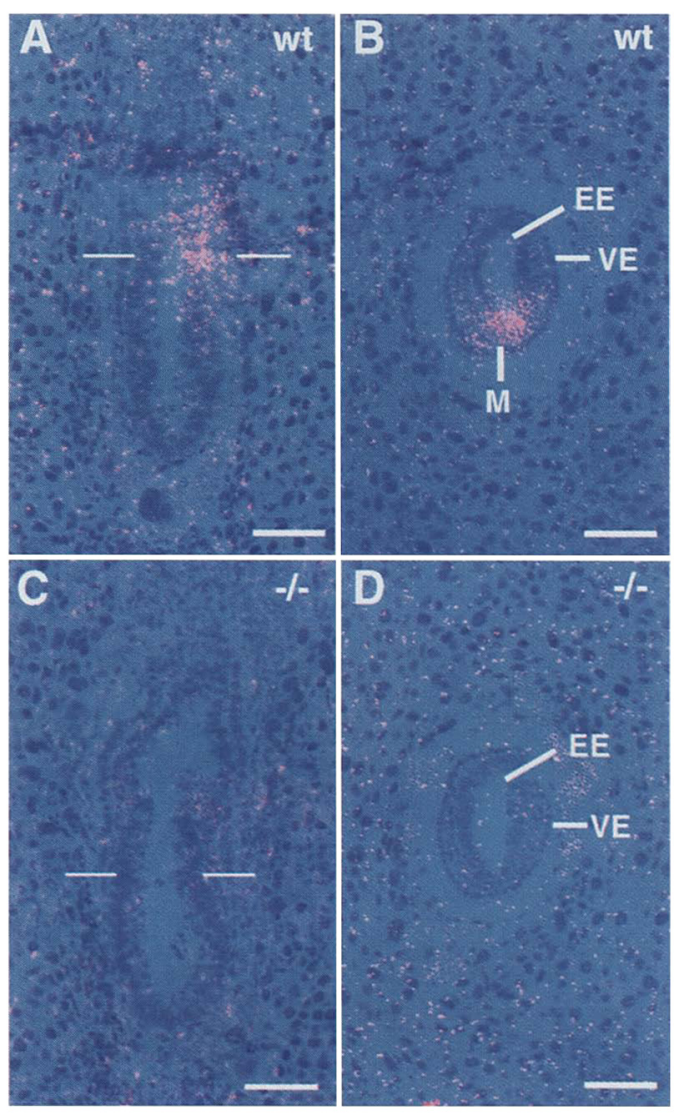

Figure 5. In situ hybridization of 6.5-day-old embryos with Brachyury probe. Sections of 6.5-dpc embryos were genotyped with the Lcrf1 probe as indicated in Fig. 3 , and adjacent sections were analyzed for Brachyury $(T)$. $(A, B)$ An Lcrf1-positive embryo that is also positive for Brachyury $(T)$ expression. No signal was detected with a sense-strand probe on other sections /data not shown). (C,D) An Lcrf1 null mutant that is also negative for Brachyury expression. $(A, C)$ Sagittal sections; $(B, D)$ transverse sections made in the plane indicated by the lines in $A$ and $C$, respectively. Transverse sections of the entire embryo depicted in $D$ were examined for $T$ expression, and none of the sections was positive. Scale bars in $A-C, 55 \mu \mathrm{m}$, and in $D, 45 \mu \mathrm{m}$. 
A

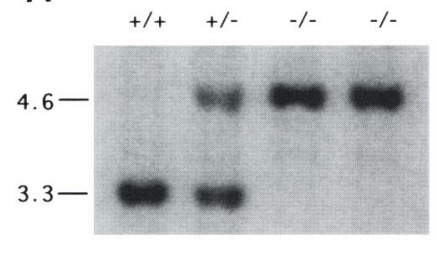

B

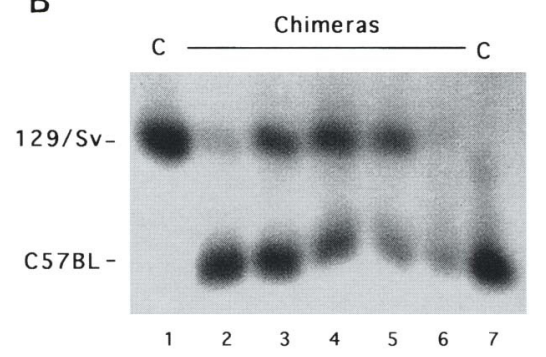

Figure 6. Analysis of chimeras produced from injection of Lcrf1 - / ES cells. (A) Southern blot analysis of DNA from Lcrf1 $+/+,+/-$, and $-/-$ ES cells digested with BamHI and hybridized with the $3^{\prime}$ probe. Positions of the endogenous $3.3-\mathrm{kb}$ band and the homologous recombinant $4.6-\mathrm{kb}$ band are indicated on the left. Analysis was also performed on BamHI-digested DNA with the Neo probe and on KpnI-digested DNA with the $5^{\prime}$ probe; the results (data not shown) were consistent with the data in Fig. 1. (B) GPI analysis of blood from chimeras produced with Lcrf1-/cells. Chimeric mice were produced by injection of Lcrf1 - / ES cells (129/Sv) into wild-type blastocysts (C57BL/6). Injected ES cells were at the same passage as cells examined in $A$. No Lcrf1positive allele could be detected in these cells. Blood from chimeras was analyzed by GPI banding. (Lanes 1 and 7) GPI bands observed in hemolysates from $129 / \mathrm{Sv}$ and C57BL/6 mice, respectively. (Lanes 2-6) GPI banding pattern in hemolysates from five chimeras that had ES cell contributions of $70 \%$ to $100 \%$ based on coat color. The results demonstrate that Lcrf1 -/- cells contribute to blood; therefore, the mutation is not cell-autonomous. Wild-type cells derived from the blastocysts rescue the mutant phenotype at gastrulation.

cells in culture (Caterina et al. 1994; Moi et al. 1994; Shivdasani and Orkin 1995); therefore, all three bZIP transcription factors may compensate for each other in vivo.

\section{Discussion}

Gastrulation in mammalian development is initiated at the posterior of the embryo at the border between embryonic epiblast (ectoderm), visceral endoderm, and extraembryonic ectoderm (Kaufman 1992; Hogan et al. 1994; Conlon and Beddington 1995). At $\sim 6.5 \mathrm{dpc}$, a small patch of columnar epithelial cells at the posterior rim of the cup-shaped epiblast delaminates and moves into the region between the ectoderm and endoderm. This structural change is propagated anteriorly and laterally to form a new structure designated the primitive streak. The streak contains a population of newly formed mesodermal cells that expands and migrates to produce a distinct third layer of tissue, the mesoderm. Subsequent to the appearance of the node at the anterior of the primitive streak, the mesoderm becomes organized into populations with different fates: axial (prechordal plate and notochord), paraxial (somites), and lateral plate (splanchnopleure and somatopleure) mesoderm. A distinct subpopulation at the posterior of the streak gives rise to the extraembryonic mesoderm of the yolk sac, and subsequently to primitive hematopoietic cells. Definitive hematopoietic cells are derived from the AGM laorta-gonad-mesonephros) region later in development (Medvinsky et al. 1993; Dzierzak and Medvinsky 1995; Cumano et al. 1996; Medvinksy and Dzierzak 1996).

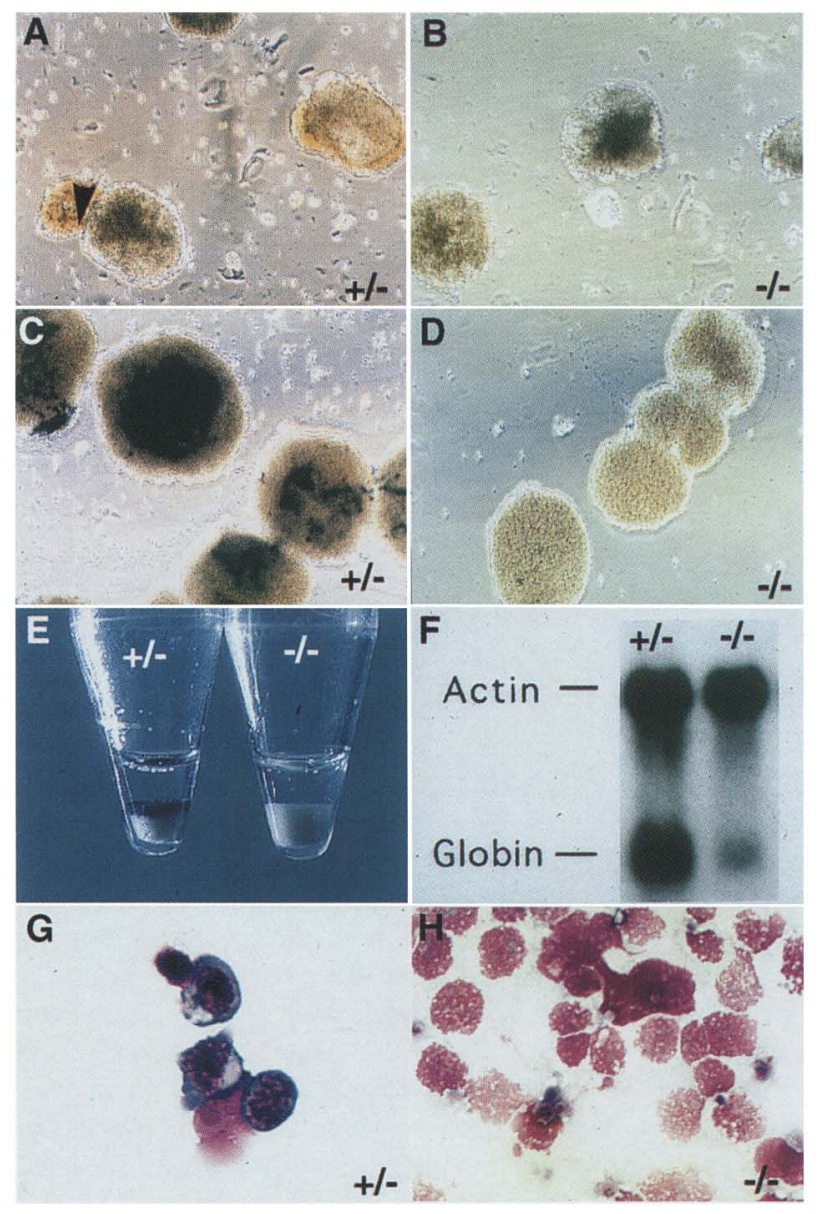

Figure 7. Analysis of EBs produced by in vitro differentiation of $L c r f 1+/$ - and - /- ES cells. $L c r f 1+/$ - and -/ - ES cells were differentiated in vitro to form EBs. Large numbers of hemoglobinized cells were observed in both unstained ( $A$, arrow) and benzidine-stained $(C)$ EBs derived from +/-ES cells; only occasional hemoglobinized cells could be identified in $-/-$ EB cultures $(B, D)$. When EB cultures were collected by centrifugation $(E)$, hemoglobinized cells were evident as a layer of blue cells in the top portion of the pellet in +/- samples but not in $-/-$ pellets. Northern blot analysis of RNA from EB cultures $(F)$ verified that globin expression was greatly reduced in the $-/-$ samples. In addition, nucleated red blood cell precursors were observed in cytospins from $+/$ - EBs $(G)$, but not from -/- EBs $(H)$. 
Over the past few years, significant progress has been made in the identification of genes required for mouse gastrulation and mesoderm formation (Copp 1995; St. Jacques and McMahon 1996). However, direct effects on mesoderm induction and specification have been difficult to distinguish from indirect effects on epiblast (ectoderm) cell proliferation and survival. Mutations in the genes encoding fibroblast growth factor 4 (FGF4) (Feldman et al. 1995) and the fibroblast growth factor receptor-1 (FGFR-1) (Deng et al. 1994; Yamaguchi et al. 1994) appear to inhibit epiblast cell proliferation and subsequent organization of the egg cylinder; consequently, mutations in these genes may have an indirect effect on mesoderm formation. Mice homozygous for the velvet coat $(V e)$ mutation also have deficient primitive ectoderm development (Rossant and Vijh 1981). In contrast, mice with mutations in the $\beta$-catenin gene or at the $F u$ locus (Jacobs-Cohen et al. 1984) die at gastrulation as a result of abnormal accumulations of ectoderm, and embryos with a null mutation in the fug1 gene have disorganized primitive ectoderm (DeGregori et al. 1994).

Other mutations inhibit normal endoderm function or the patterning of mesoderm. Mice with a deleted $\beta 1$ integrin gene have an apparent defect in embryonic endoderm morphogenesis and migration that affects mesoderm formation (Fassler and Meyer 1995; Stephens et al. 1995). In mice with mutations in the genes encoding protein tyrosine kinase focal adhesion kinase (FAK) (Furuta et al. 1995; Ilic et al. 1995) or fibronectin (George et al. 1993), mesoderm formation begins but is incomplete because of apparent effects on cell adhesion and motility. Similarly, mice with mutations in the Huntington disease $(H d h)$ gene initiate normal primitive streak formation but die later in development $(8.5 \mathrm{dpc})$ as a result of effects on mesodermal growth and differentiation (Duyao et al. 1995; Nasir et al. 1995; Zeitlin et al. 1995).

Mutations in genes encoding two transforming growth factor- $\beta$ (TGF- $\beta$ )-like factors (NODAL and BMP4) have been implicated in mesoderm induction. A null mutation in the nodal gene (Conlon et al. 1991; Collignon et al. 1996) inhibits normal primitive streak and node formation. Consequently, mesodermal cell patterning is abnormal, and mutant embryos die between 8.0 and $9.0 \mathrm{dpc}$ with extensive overgrowth of the ectoderm. Mesoderm formation is also inhibited in mice with null mutations in Bmp4 (bone morphogenetic protein 4) (Winnier et al. 1995) and $A L K 3$ (Bmprl A receptor) (Mishina et al. 1995). These mutations arrest the development of most mouse embryos at $6.5 \mathrm{dpc}$. This phenotype suggests that BMP4 is critical for mesoderm induction and that BMPR $1 A$ tranduces signals important for mesoderm formation. However, epiblast cell proliferation and organization are also affected in Bmpr1A mutant embryos; therefore, reductions in mesoderm may be an indirect effect.

Previously, no transcription factor directly involved in mesoderm formation has been described. Brachyury $(T)$ is a transcription factor expressed in primitive mesoderm; however, early mesoderm formation and gastrulation occur normally in $T$ null mutants. These mutants have a cell-autonomous effect that inhibits later devel- opment of posterior mesoderm and notochord (Beddington et al. 1992; Herrmann 1992; Herrmann and Kispert 1994), possibly by affecting cell migration. Hepatocyte nuclear factors 4 (HNF4) and $3 \beta$ (HNF3 $\beta$ ) are also transcription factors expressed in the embryo at $6.5 \mathrm{dpc}$, but null mutations in these genes result in embryonic death later in development (Ang and Rossant 1994; Chen et al. 1994; Weinstein et al. 1994). HNF4 is required for completion of gastrulation. The $h n f 4$ gene is expressed in primitive endoderm, and in its absence ectoderm dies, possibly as a result of the absence of a nutrient factor from endoderm (Chen et al. 1994). A null mutation in the $h n f 3 \beta$ gene inhibits node and notochord formation. In this case, mesoderm is formed but is not correctly patterned. Mesoderm is not formed in embryos lacking the transcription factor MDM2 (de Oca Luna et al. 1995; Jones et al. 1995) or the putative transcription factor BRCAl (Gowen et al. 1996; Hakem et al. 1996; Jensen et al. 1996; Liu et al. 1996); however, these mesoderm deficiencies apparently result from cell cycle delays in the early egg cylinder. Mutations in the transcription factor genes Lim1 (Shawlot and Behringer 1995), Otx2 (Acampora et al. 1995; Matsuo et al. 1995; Ang et al. 1996), twist (Chen and Behringer 1995), and Notch1 (Swiatek et al. 1994; Conlon et al 1995/ all affect development of specific subpopulations of mesoderm later in development. Finally, mutations in the eed gene (for embryonic ectoderm development), which encodes a member of the Polycomb group (Pc-G) of transcriptional repressors, alters primitive streak patterning (Faust et al. 1995; Schumacher et al. 1996). Formation of the streak is initiated, but anterior-posterior patterning before segmentation is disrupted, and most null mutants die at the mid-streak stage.

\section{Lcrf1 mutation inhibits mesoderm formation}

We report here the first example of a transcription factor that is essential for gastrulation of phenotypically normal, late egg cylinder embryos. As indicated above, mutations described previously either inhibit normal egg cylinder development or alter mesodermal patterning after gastrulation has been initiated. $\operatorname{Lcrf} 1^{\text {tm1uab }}$ homozygous mutant embryos develop normally to the late egg cylinder stage at $\sim 6.5 \mathrm{dpc}$, but most die before $7.5 \mathrm{dpc}$. Mutant embryos fail to form a primitive streak and are unable to produce mesoderm. These results demonstrate that LCR-F1 is essential for gastrulation in the mouse and suggest that mutation of this gene has a direct effect on mesoderm induction.

It is theoretically possible that expression of an adjacent or overlapping gene is altered by our mutation. However, the mutant phenotype is clearly consistent with inactivation of the Lcrf1 gene that is developmentally regulated. RT-PCR and in situ hybridization results demonstrate that Lcrf1 expression is activated at a high level between 3.5 and $6.5 \mathrm{dpc}$. This tightly regulated pattern of expression strongly suggests a key role for LCRF1 in early development.

One possible target for LCR-F1 regulation in early de- 
velopment is the nodal gene that encodes a TGF- $\beta$-like factor secreted by ectodermal cells at the egg cylinder stage (Zhou et al. 1993; Conlon et al. 1994). Homozygous nodal mutants fail to form a distinct primitive streak and most mesoderm (Conlon et al. 1991; Collignon et al. 1996). However, nodal -/ - ES cells contribute to mesoderm when the cells are injected into wild-type blastocysts (Conlon et al. 1991). This lack of cell autonomy is consistent with the role of NODAL protein as a secreted, signaling factor affecting mesodermal cell fate (Conlon et al. 1991; Jones et al. 1995; Collignon et al. 1996). As demonstrated above, the effect of the $\operatorname{Lcrf} 1^{\text {tm1uab }}$ mutation is also non-cell-autonomous, suggesting that it regulates expression of genes encoding a secreted factor or a cell surface molecule capable of inducing mesoderm, and nodal is certainly a candidate. However, nodal mutants do express some $T$ and die later in development 18.0-9.0 dpc) than Lcrf1 -/- mutants, suggesting that LCR-F1 must regulate other genes. The Bmp4 gene is also a potential target. However, the phenotypes of null mutations in these genes are also distinct from the Lcrf1 - /phenotype. Null mutations in Bmp4 and Bmpr1A appear to retard epiblast growth in the egg cylinder (Mishina et al. 1995; Winnier et al. 1995), and egg cylinder development in Lcrf $1^{\text {tmluab }}$ mutants appears normal. Alternatively, LCR-F1 may regulate a novel factor that functions alone or in conjunction with BMP4 and NODAL to induce mesoderm. Subtractive hybridization (Sive and St. John 1988) or differential display (Liang and Pardee 1992) techniques using $L c r f 1+/-$ and $-/$ - embryos at $6.5 \mathrm{dpc}$ could be used to identify novel factors. The isolation of leucine zipper proteins that heterodimerize with LCR-F1 at 6.5 days of development may also facilitate the identification of targets for LCR-F1 regulation. Proteins isolated by yeast two-hybrid screens of 6.5 -dpc cDNA libraries may yield relevant partners. Heterodimers could then be used to define binding sites (Pollock and Treisman 1990; Szostak 1992) and, subsequently, target genes (Kinzler and Vogelstein 1989; Wright and Funk 1993).

\section{The role of LCR-F1 in globin gene regulation}

Why is LCR-F1 not required for globin gene expression? The simplest answer is that LCR-F1, NF-E2 p45, and NRF2 can compensate for each other's absence in mutant animals. All three proteins are related, bZIP transcription factors that are expressed in erythroid cells; however, none of the null mutations in these genes significantly affects globin gene expression in vivo (LCR-F1 this paper; NF-E2, Shivdasani and Orkin 1995; Shivdasani et al. 1995; NRF2, Chan et al. 1996). Combinations of null mutations in these genes may result in a globin phenotype, but it is also possible that other CNC family members are involved in globin gene regulation. The AP1-like sites (designated NF-E2 sites) that these factors bind in the $\beta$-globin LCR are critical for globin gene expression, but further experiments are required to determine whether LCR-F1, NF-E2, NRF2, and/or other proteins function at these sites.

In summary, a null mutation in the murine Lcrf1 gene is embryonic lethal. Lcrf $1^{\text {tm1uab }}$ mutant embryos progress normally to the late egg cylinder stage, but development is arrested at $\sim 6.5 \mathrm{dpc}$. Remarkably, egg cylinder growth and organization does not appear to be affected in Lcrf $1^{\text {tm1uab }}$ mutants. Mutant embryos developed normally until $6.5 \mathrm{dpc}$ but failed to form a demonstrable primitive streak and were unable to produce mesoderm. Homozygous mutant ES cells are rescued after injection into wild-type blastocysts, and mutant ES cells contribute to all cell lineages examined in these chimeras, indicating that the Lcrf1 mutation is not cell-autonomous. These results demonstrate that LCR-F1 is essential for gastrulation in the mouse and suggest that this transcription factor controls expression of genes that are critical for the earliest signaling events in mesoderm formation.

\section{Materials and methods}

Mutagenesis of the Lcrfl gene in mouse ES cells

A $129 / \mathrm{Sv}$ mouse $\lambda$ genomic library (Stratagene) was screened with a human Lcrf1 cDNA probe (Caterina et al. 1994). Several positive clones were obtained, and the genomic organization of the longest $(13.5 \mathrm{~kb})$ was analyzed by restriction enzyme mapping and sequence analysis. A 5.0-kb BamHI $5^{\prime}$ fragment and a 1.7-kb HindIII-Sau3A 3' fragment were used to construct a replacement gene targeting vector (Fig. 1A; the Sau3A site was converted to SalI|). These fragments were subcloned into the BamHI and HindIII-SalI sites, respectively, of the plasmid pNTK (Mortensen et al. 1992; Ausubel et al. 1994). The targeting vector was linearized with NotI and $25 \mu \mathrm{g}$ of this vector were electroporated into $2 \times 10^{7} \mathrm{ES}$ cells in $1 \mathrm{ml}$ total volume of ES cell media in a $0.4-\mathrm{cm}$ gap cuvette at $400-450 \mathrm{~V}$ and $200-250 \mu \mathrm{f}$ (BioRad Gene Pulser). Two lines of ES cells were used: the D3 line (a gift from Dr. Tom Doetschman, University of Cincinnati, Ohio) and the R1 line (a gift from Dr. Andras Nagy, Mt. Sinai Hospital, Toronto, Canada). All ES cells were maintained under standard conditions and grown on mouse primary embryonic fibroblast feeder layers before electroporation and during selection and expansion (Robertson 1987; T. Doetschman and Andras Nagy, pers. comm.). Twenty-four hours after electroporation, selection was initiated in media that contained G418 (Geneticin, $300 \mu \mathrm{g} / \mathrm{ml}$ of active concentration, GIBCO/BRL) and gancyclovir (2-2.5 $\mu$; a generous gift from Syntex). Selection media was replaced every $48 \mathrm{hr}$. Surviving colonies were picked after 12-14 days of selection and placed into individual wells of a 24-well plate of feeder layers containing media without selection agents. Colonies were dispersed by trypsinization 24-48 hr later and subsequently expanded for storage by freezing and for extraction of DNA. Homologous recombinants were identified by Southern blot analysis (Fig. 6A; data not shown) performed by standard procedures (Ausubel et al. 1994). The targeting frequency for the Lcrf1 gene was 1 in 76 for D3 ES cells and 1 in 44 for R1 ES cells. Correctly identified homologous recombinants were checked using standard methods for the absence of mycoplasma contamination (Del Guidice and Hopps 1978) and for euploidy (Robertson 1987; P. Detloff, pers. comm.) before they were used for mouse production.

Generation of chimeric mice and germ-line transmission of the Lcrf $1^{\text {tmluab }}$ mutant allele

ES cells were injected into 3.5-day-old C57BL/6 mouse blastocysts by standard methods (Bradley 1987; Hogan et al 1994). 
Injected blastocysts were surgically placed into the uterus of pseudopregnant $\mathrm{CD} 1$ female recipient mice and allowed to develop to term to produce chimeras. Two clones of $L c r f 1^{\text {tm } 1 \text { iuab }}$ $-/-$ D3 cells were used to generate the chimeras for GPI analysis. One clone of $L c r f 1^{\text {tmluab }}+/-\mathrm{R} 1$ cells was used to generate germ-line chimeras that were mated to Black Swiss outbred mice to generate animals heterozygous for the deletion. Heterozygotes were identified by Southern blot and/or PCR analysis (Ausubel et al. 1994) of tail DNA from agouti offspring. The strategies for Southern blot and PCR analysis are described in Figure 1 and in the text. All embryos described here were from the $129 / \mathrm{Sv} \times$ Black Swiss mixed genetic background; information on the Lcrf $1^{\text {tm1uab }}$ construct and these mice has been submitted to TBASE (http://www.gdb.org/Dan/tbase/tbase.html). The mutant allele was designated Lcrf $1^{\text {tm Iuab }}$ according to standard nomenclature (Davisson 1995). Most embryos were genotyped by PCR after dissection (in PBS with $4 \%$ BSA) to remove all maternal tissues and Reichert's membrane. PCR primers were made to a region of the Lcrf1 gene that was deleted in the homologous recombinant allele and to the neomycin resistance cassette, which was present only in the recombinant allele. Lcr$\mathrm{fl}$ primers were as follows: forward primer $5^{\prime}$-CCACCCAGCACCCTCAAGAA-3' and reverse primer 5'-GCAGCCGCCCAAACACCTCCT-3'. Neomycin resistance cassette primers were: forward primer $5^{\prime}$-CGCCCGGTTCTTTTTGTC-3' and reverse primer 5'-GCGGCCATTTTCCACCAT-3'. Samples were amplified for 32 cycles of denaturation for $1 \mathrm{~min}$ at $94^{\circ} \mathrm{C}$, annealing for $1 \mathrm{~min}$ at $59^{\circ} \mathrm{C}$, and elongation for $1 \mathrm{~min}$ at $68^{\circ} \mathrm{C}$. Embryos at $6.5 \mathrm{dpc}$ were genotyped by in situ hybridization of tissue sections as described below.

\section{Preparation of slides and histological analysis of embryos}

Intact decidua produced from timed matings between heterozygotes were dissected in ice-cold PBS with $4 \mathrm{mg}$ per $\mathrm{ml}$ BSA (Sigma) and fixed in $4 \%$ paraformaldehyde in PBS at $4^{\circ} \mathrm{C}$ overnight. Decidua were dehydrated in a series of ascending concentrations of methanol and cleared in xylene. Decidua were then incubated in molten paraplast and embedded. Sections 7-10 $\mu \mathrm{m}$ thick were cut and mounted (Permount) onto Superfrost Plus slides (Fisher Scientific). Slides were dewaxed and rehydrated by standard procedures then used for staining or in situ hybridization. Staining was performed by standard procedures using hematoxylin/eosin.

\section{In situ hybridization analysis}

In situ hybridization with $\alpha{ }^{-35}$ S-labeled UTP RNA probes was performed essentially as described (Zhao and Hogan 1996; Zhao et al. 1996) with modifications. $L c r f 1$ and $T$ probes were used to detect mRNA in sections of embryos in decidua. The Lcrf1 probe contained the $5^{\prime} 1153$ bp of exon 6 . This probe hybridized within the area deleted in the $\operatorname{Lcrf} 1^{\text {tmluab }}$ mutation; therefore, the probe could be used to distinguish $+1+$ and $+1-$ from $-/-$ embryos. The $T$ probe was a full-length mouse cDNA (1400 bp). To assess $T$ expression, serial transverse sections covering the entire length of selected embryos were examined. Briefly, sections prepared as described above were treated with $20 \mu \mathrm{g} / \mathrm{ml}$ of proteinase K. Hybridization was carried out overnight at $50^{\circ} \mathrm{C}$ in a solution containing $40 \%$ formamide, $0.3 \mathrm{M} \mathrm{NaCl}, 10 \mathrm{~mm}$ Tris-HCl (pH 7.5), $10 \mathrm{~mm}$ sodium phosphate, 10\% dextran sulfate, $8 \mathrm{~mm}$ DTT, $5 \mathrm{~mm}$ EDTA, $1 \times$ Denhardt's solution, $0.2 \mu \mathrm{g} /$ $\mathrm{ml}$ tRNA, and $2 \times 10^{6} \mathrm{cpm} / \mathrm{ml}$ of probe solution. Slides were washed once for $30 \mathrm{~min}$ at high stringency $\left(60^{\circ} \mathrm{C}\right)$ in $50 \%$ formamide, $2 \times$ SSC, $20 \mathrm{mM} 2$-mercaptoethanol, and twice for $10 \mathrm{~min}$ each at $37^{\circ} \mathrm{C}$ in $4 \times \mathrm{SSC}, 20 \mathrm{~mm}$ Tris $\mathrm{HCl}(\mathrm{pH} 7.4), 2$ mM EDTA, and then were digested once at $37^{\circ} \mathrm{C}$ for $30 \mathrm{~min}$ with $20 \mu \mathrm{g} / \mathrm{ml}$ of RNase A in $4 \times$ SSC, $20 \mathrm{~mm}$ Tris $\mathrm{HCl}$ ( $\mathrm{pH} 7.4), 2$ mm EDTA. Slides were then washed once at $37^{\circ} \mathrm{C}$ for $10 \mathrm{~min}$ in $4 \times \mathrm{SSC}, 20$ $\mathrm{mM}$ Tris $\mathrm{HCl}$ ( $\mathrm{pH} 7.4), 2 \mathrm{~mm}$ EDTA, $20 \mathrm{~mm}$ 2-mercaptoethanol, and once at $60^{\circ} \mathrm{C}$ for $15 \mathrm{~min}$ in $50 \%$ formamide, $2 \times$ SSC, $20 \mathrm{~mm}$ 2-mercaptoethanol. The slides were washed at $37^{\circ} \mathrm{C}$ for $10 \mathrm{~min}$ in $2 \times \mathrm{SSC}$ and for $5 \mathrm{~min}$ at room temperature in $0.1 \times \mathrm{SSC}$. Slides were then rinsed in deionized water and air-dried. Slides were dipped in Kodak NTB-2 emulsion diluted 1:1 with deionized water. After a 1-week exposure, the slides were developed in Kodak D-19 developer for $2 \mathrm{~min}$ at room temperature, rinsed in tap water for $30 \mathrm{sec}$ at room temperature, and immersed in Kodak fixer for $5 \mathrm{~min}$ at room temperature. Slides were then rinsed in deionized water for $10 \mathrm{~min}$ at room temperature, counterstained in eosin, examined, and photographed.

\section{RT-PCR analysis}

RNA was isolate essentially as described (Chomczynski and Sacchi 1987) from pools of 60-70 wild-type 3.5-day-old blastocysts, from 100-mm plate cultures of undifferentiated wild-type ES cells, or from $100-\mathrm{mm}$ plate cultures of $+/-$ or $-/$ - embryoid bodies. Before RNA isolation, ES cells were grown on gelatincoated plates in high concentrations of LIF (leukemia inhibitory factor) and in the absence of primary embryonic fibroblast feeder layers for five passages. cDNA was synthesized from isolated RNA using the cDNA Cycle Kit (Invitrogen), and PCR was performed by standard procedures (Ausubel et al. 1994). Lcrf1 primers were forward primer 5 -CCAGAAGGAGCAGGATGTGGA-3', which is located in exon 3 , and reverse primer $5^{\prime}$ GCAGCCGCCCAAACACCT CCT-3', which is located in exon 6. Hprt primers were forward primer 5'-GCTGGTGAAAAGGACCTCT- $3^{\prime}$ and reverse primer 5'-CACAGGACTAGAACACCTGC- $3^{\prime}$. Both Lcrf1 and Hprt primers were designed to span introns. Samples were amplified for 32 cycles of denaturation for $1 \mathrm{~min}$ at $94^{\circ} \mathrm{C}$, annealing for $1 \mathrm{~min}$ at $58^{\circ} \mathrm{C}$, and elongation for $2 \mathrm{~min}$ at $68^{\circ} \mathrm{C}$. Separate PCR reactions were performed with the Lcrf1 and Hprt primers on the same amount of cDNA. The products were then mixed at a $3: 1$ ratio (Lcrf1 to Hprt) and electrophoresed on a $1 \%$ agarose gel.

\section{GPI analysis}

Separation and detection of glucose phosphate isomerase (GPI) isoenzymes were performed by standard procedures (Nagy and Rossant 1993). Samples were prepared by homogenizing tissues as described, and cells were lysed by three rounds of freezing and thawing. Cellulose acetate plates were soaked in Tris-glycine buffer for $15 \mathrm{~min}$ prior to application of samples. Five microliters of each sample were applied to the plate. Samples were electrophoresed for $90 \mathrm{~min}$ at $300 \mathrm{~V}$ at room temperature. Ten milliliters of $1 \%$ agarose containing $10.8 \mathrm{mg}$ magnesium acetate, $15 \mathrm{mg}$ of fructose- 6 -phosphate $(\mathrm{F} 6 \mathrm{P}), 2 \mathrm{mg} \beta$-nicotinamide adenine dinucleotide phosphate (NADPH), $0.36 \mathrm{mg}$ of phenazine methosulfate (PMS), and $2 \mathrm{mg}$ of methylthiazolium tetrazolium (MTT) at $55^{\circ} \mathrm{C}$ were mixed with 10 units of glucose6-phosphate dehydrogenase (G6P-DH) and immediately poured over the cellulose acetate plate. The plate was incubated for 10 min at $37^{\circ} \mathrm{C}$ in the dark and was then fixed in $1: 3$ acetic acid to glycerol for $10 \mathrm{~min}$. Results were recorded by photography. Hemolysates from whole blood were analyzed as illustrated in Figure 6B. Although the GPI activity in white blood cells (WBCs) is 100-fold higher than the activity in red blood cells (RBCs) (Warner et al. 1985), there are normally 100,000 more RBCs than WBCs in mouse blood (Jacoby and Fox 1984). Therefore, 
virtually all $(99.9 \%)$ of the GPI activity in whole blood is derived from RBCs.

\section{Embryoid body in vitro cultures and analysis}

Heterozygous Lcrf1 mutant ES cells were converted to homozygosity by growth in the presence of high concentrations of G418 (Mortensen et al. 1992; Ausubel et al. 1994). In these experiments, two independent lines of D3 ES cells heterozygous for the Lcrf1 mutation were grown in media containing 2000

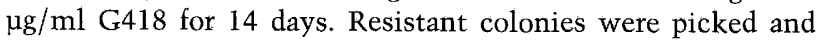
tested for homozygosity by Southern blot analysis (Fig. 6; data not shown). Heterozygous $(+\mid-)$ and homozygous mutant $(-/-)$ ES cells were subsequently grown in isolation in methylcellulose cultures (Wiles 1993) containing erythropoietin (Amgen) for 10 days to induce differentiation into EBs containing erythroid cells. Heterozygous lines used for controls were obtained from the same $2000 \mu \mathrm{g} / \mathrm{ml} \mathrm{G} 418$ plates as the homozygous cells; these cells represent colonies that survived increased selection but did not gene convert to homozygosity for the mutation. Wet mounts of embryoid bodies were then analyzed for hemoglobin production with and without benzidine (Sigma) staining (Doetschman et al. 1985; Pearse 1985; Stevens 1990). In addition, populations of either $+/$ - or $-/$ - benzidine-stained EBs were collected by centrifugation, and the amount of stain present in the resulting pellets was assessed. Isolation of RNA from the EBs was performed by the guanidine thiocyanate method (Chomczynski and Sacchi 1987). Northern blot analysis was performed using standard procedures (Ausubel et al. 1994; Caterina et al. 1994). Cytospin preparations of EBs derived from +/- and -/- ES cells were stained with Dip Quick (Jorgensen Laboratories). Identical results were obtained from two LCR-F1 -/- D3 clones.

\section{Acknowledgments}

We thank Dr. Tom Doetschman and Dr. Andras Nagy for D3 and R1 ES cell lines, respectively, Dr. Pete Detloff for the procedure for chromosome counting, and Dr. Richard Mortensen for the pNTK vector. We gratefully acknowledge Dr. David Donze for discussions and for performing the Northern blot analysis. We also thank Syntex for the generous gift of gancyclovir. This work was supported by National Institutes of Health grants RR00107 to S.C.F. and HL35559 to T.M.T. B.L.M.H. is an Investigator of the Howard Hughes Medical Institute.

The publication costs of this article were defrayed in part by payment of page charges. This article must therefore be hereby marked "advertisement" in accordance with 18 USC section 1734 solely to indicate this fact.

\section{References}

Acampora, D., S. Mazan, Y. Lallemand, V. Avantaggiato, M. Maury, A. Simeone, and P. Brulet. 1995. Forebrain and midrain regions are deleted in Otx2 $-/-$ mutants due to a defective anterior neuroectoderm specification during gastrulation. Development 121: 3279-3290.

Ang, S.-L. and J. Rossant. 1994. HNF-3 $\beta$ is essential for node and notochord formation in mouse development. Cell 78: 561574.

Ang, S.-L., O. Jin, M. Rhinn, N. Daigle, L. Stevenson, and J. Rossant. 1996. A targeted mouse Otx2 mutation leads to severe defects in gastrulation and formation of axial mesoderm and deletion of rostral brain. Development 122: 243252.
Ausubel, F.M., R. Brent, R.E. Kingston, D.D. Moore, J.G. Seidman, J.A. Smith, K. Struhl, L.M. Albright, D. Coen, M.A. Varki, and K. Janssen. 1994. Current protocols in molecular biology. John Wiley and Sons, New York, NY.

Beddington, R.S.P., P. Rashbass, and V. Wilson. 1992. Brachyury-A gene affecting mouse gastrulation and early organogenesis. Development (Suppl.): 157-165.

Bowerman, B., B.A. Eaton, and J.R. Priess. 1992. skn-1, a maternally expressed gene required to specify the fate of ventral blastomeres in the early C. elegans embryo. Cell 68: 10611075.

Bowerman, B., B.W. Draper, C.C. Mello, and J.R. Priess. 1993. The maternal gene skn-1 encodes a protein that is distributed unequally in early C. elegans embryos. Cell 74: 443452.

Bradley, A. 1987. Production and analysis of chimaeric mice. In Teratocarcinomas and embryonic stem cells: a practical approach, 1st ed. (ed. Elizabeth J. Robertson), pp.113-152. IRL Press, Oxford, UK.

Caterina, J.J., T.M. Ryan, K.M. Pawlik, R.D. Palmiter, R.L. Brinster, R.R. Behringer, and T.M. Townes. 1991. Human $\beta$-globin locus control region: Analysis of the 5' DNase I hypertensive site HS 2 in trangenic mice. Proc. Natl. Acad. Sci. 88: 1626-1630.

Caterina, J.J., D. Donze, C.-W. Sun, D.J. Ciavatta, and T.M. Townes. 1994. Cloning and functional characterization of LCR-F1: A bZIP transcription factor that activates erythroid specific, human globin gene expression. Nucleic Acids Res. 22: 2383-2391.

Chan, J.Y., X.-L. Han, and Y.W. Kan. 1993. Cloning of Nrf1, an NF-E2-related transcription factor, by genetic selection in yeast. Proc. Natl. Acad. Sci. 90: 11371-11375.

Chan, K., R. Lu, J.C. Chang, and Y.W. Kan. 1996. NRF2, a member of the NFE2 family of transcription factors is not essential for murine erythropoiesis, growth, and development. Proc. Nat1. Acad. Sci. 93: 13943-13948.

Chen, W.S., K. Manova, D.C. Weinstein, S.A. Duncan, A.S. Plump, V.R. Prezioso, R.F. Bachvarova, and J.E. Darnell, Jr. 1994. Disruption of the HNF-4 gene, expressed in visceral endoderm, leads to cell death in embryonic ectoderm and impaired gastrulation of mouse embryos. Genes \& Dev. 8: $2466-2477$.

Chen, Z.-F. and R.R. Behringer. 1995. twist is required in head mesenchyme for cranial neural tube morphogenesis. Genes \& Dev. 9: 686-699.

Chomczynski, P. and N. Sacchi. 1987. Single-step method of RNA isolation by acid guanidinium thiocyanite-phenolchloroform extraction. Anal. Biochem. 162: 156-159.

Collignon, J., I. Varlet, and E.J. Robertson. 1996. Relationship between asymmetric nodal expression and the direction of embryonic turning. Nature 381: 155-158.

Conlon, F. and R. Beddington. 1995. Mouse gastrulation from a frog's perspective. Semin. Dev. Biol. 6: 249-256.

Conlon, F.L., K.S. Barth, and E.J. Robertson. 1991. A novel retrovirally induced embryonic lethal mutation in the mouse: Assessment of the developmental fate of embryonic stem cells homozygous for the 413.d proviral integration. Development 111: 969-981.

Conlon, F.L., K.M. Lyons, N. Takaesu, K.S. Barth, A. Kispert, B. Herrman, and E.J. Robertson. 1994. A primary requirement for nodal in the formation and maintenance of the primitive streak in the mouse. Development 120: 1919-1928.

Conlon, R.A., A.G. Reaume, and J. Rossant. 1995. Notch1 is required for the coordinate segmentation of somites. Development 121: 1533-1545.

Copp, A.J. 1995. Death before birth: Clues from gene knockouts 
and mutation. Trends Genet. 11: 87-93.

Cumano, A., F. Dieterlen-Lievre, and I. Godin. 1996. Lymphoid potential, probed before circulation in mouse, is restricted to caudal intraembryonic splanchnopleura. Cell 86: 907-916.

Davisson, M.T. 1995. Genetic nomenclature guide (mouse). In Trends in genetic nomenclature guide (ed. A. Stewart), pp. 35-38. Elsevier Trends Journals, Kidlington, Oxford, UK.

de Oca Luna, R.M., D.S. Wagner, and G. Lozano. 1995. Rescue of early embryonic lethality in $\mathrm{mdm}-2$ deficient mice by deletion of p53. Nature 378: 203-206.

DeGregori, J., A. Russ, H. von Melcher, H. Rayburn, P. Priyarenjan, N.A. Jenkins, N.G. Copeland, and H.E. Ruley. 1994. A murine homolog of the yeast RNAl gene is required for postimplantation development. Genes \& Dev. 8: 265-276.

Del Guidice, R.A. and H.E. Hopps. 1978. Microbiological methods and flourescent microscopy for the direct demonstration of mycoplasma infection of cell cultures. In Mycoplasmal infection of cell cultures (ed. Gerard J. McGarrit, Donald G. Murphy, and Warren W. Nichols), pp.57-69. Plenum Press, New York, NY.

Deng, C.-X., A. Wynshaw-Boris, M.M. Shen, C. Daugherty, D.M. Ornitz, and P. Leder. 1994. Murine FGFR-1 is required for early postimplantation growth and axial organization. Genes \& Dev. 8: 3045-3057.

Dillon, N. and F. Grosveld. 1993. Transcriptional regulation of multigene loci: Multilevel control. Trends Genet. 9: 134137.

Doetschman, T.C., H. Eistetter, M. Katz, W. Schmidt, and R. Kemler. 1985. The in vitro development of blastocyst-derived embryonic stem cell lines: Formation of visceral yolk sac, blood islands and myocardium. I. Embryol. Exp. Morphol. 87: 27-45.

Duyao, M.P., A.B. Auerbach, A. Ryan, F. Persichetti, G.T. Barnes, S.M. McNeil, G. Pei, J.-P. Vonsattel, J.F. Gusella, A.L. Joyner, and M.E. MacDonald. 1995. Inactivation of the mouse Huntington's disease gene homolog Hdh. Science 269: 407-410.

Dzierzak, E. and A. Medvinsky. 1995. Mouse embryonic hematopoiesis. Trends Genet. 11: 359-366.

Fassler, R. and M. Meyer. 1995. Consequences of lack of $\beta 1$ integrin gene expression in mice. Genes \& Dev. 9: 18961908.

Faust, C., A. Schumacher, B. Holder, and T. Magnuson. 1995. The eed mutation distrupt anterior mesoderm production in mice. Development 121: 273-285.

Feldman, B., W. Poueymirou, V.E. Papaionnou, T.M. DeChiara, and M. Goldfarb. 1995. Requirement of FGF-4 for postimplantation mouse development. Science 267: 246-249.

Furuta, Y., D. Ilic, S. Kanazawa, N. Takeda, T. Yamamoto, and S. Aizawa. 1995. Mesodermal defect in late phase of gastrulation by a targeted mutation of focal adhesion kinase, FAK. Oncogene 11: 1989-1995.

George, E.L., E.N. Georges-Labousse, R.S. Patel-King, H. Rayburn, and R.O. Hynes. 1993. Defects in mesoderm, neural tube and vascular development in mouse embryos lacking fibronectin. Development 119: 1079-1091.

Gowen, L.C., B.L. Johnson, A.M. Latour, K.K. Sulik, and B.H. Koller. 1996. Bracl deficiency results in early embryonic lethality characterized by neuroepithelial abormalities. $\mathrm{Na}$ ture Genet. 12: 191-194.

Haegel, H., L. Larue, M. Ohsugi, L. Fedorov, K. Herrenknecht, and R. Kemler. 1995. Lack of $\beta$-catenin affects mouse development at gastrulation. Development 121: 3529-3537.

Hakem, R., J.L. de la Pompa, C. Sirard, R. Mo, M. Woo, A. Hakem, A. Wakeham, J. Potter, A. Retmair, F. Billia, E. Firpo, C.C. Hui, J. Roberts, J. Rossant, and T.W. Mak. 1996.
The tumor suppressor gene Brcal is required for embryonic cellular proliferation in the mouse. Cell 85: 1009-1023.

Hardison, R., K.M. Chao, S. Schwartz, N. Stojanovic, M. Ganetsky, and W. Miller. 1994. Globin gene server: A prototype E-mail database server featuring extensive multiple alignments and data compilation for electronic genetic analysis. Genomics 21: 344-353.

Herrmann, B.G. 1992. Action of the Brachyury gene in mouse embryogenesis. Postimplantation Development in the Mouse, CIBA Found. Symp. 165: 78-91.

Herrmann, B.G. and A. Kispert. 1994. The T gene in embryogenesis. Trends Genet. 10: 280-286.

Hogan, B., R. Beddington, F. Costantini, and E. Lacy. 1994. Manipulating the mouse embryo, a laboratory manual. Cold Spring Harbor Laboratory Press, Cold Spring Harbor, NY.

Ilic, D., Y. Furuta, S. Kanazawa, N. Takeda, K. Sobue, N. Nakatsuji, S. Nomura, J. Fujimoto, M. Okada, T. Yamamoto, and S. Aizawa. 1995. Reduced cell motility and enhanced focal adhesion contact formation in cells from FAK-deficient mice. Nature 377: 539-544.

Jacobs-Cohen, R.J., M. Spiegelman, J.C. Cookingham, and D. Bennett. 1984. Knobby, a new dominant mutation in the mouse that affects embryonic ectoderm organization. Genet. Res. 43: 43-50.

Jacoby, R.O. and J.G. Fox. 1984. Biology and disease of mice. In Laboratory animal medicine (ed. James G. Fox, Bennett J. Cohen, and Franklin M. Loew), pp. 31-89. Academic Press, Orlando, FL.

Jensen, R.A., M.E. Thompson, T.L. Jetton, C.I. Szabo, R. van der Meer, B. Helou, S.R. Tronick, D.L. Page, M.-C. King, and J.T. Holt. 1996. BRCAl is secreted and exhibits properties of a granin. Nature Genet. 12: 303-308.

Jones, C.M., M.R. Kuehn, B.L.M. Hogan, J.C. Smith, and C.V.E. Wright. 1995. Nodal-related signals induce axial mesoderm and dorsalize mesoderm during gastrulation. Development 121: 3651-3662.

Jones, S.N., A.E. Roe, L.A. Donehower, and A. Bradley. 1995. Rescue of embryonic lethality in Mdm-2 defecient mice by absence of p53. Nature 378: 206-208.

Kaufman, M.H. 1992. The atlas of mouse development. Academic Press, San Diego, CA.

Kinzler, K.W. and B. Vogelstein. 1989. Whole genome PCR: Application to the identification of sequences bound by gene regulatory proteins. Nucleic Acids Res. 17: 3645-3653.

Kispert, A. and B.G. Herrmann. 1994. Immunohistochemical analysis of the Branchyury protein in wild-type and mutant mouse embryos. Dev. Biol. 161: 179-193.

Liang, P. and A.B. Pardee. 1992. Differential display of eukaryotic messenger RNA by means of the polymerase chain reaction. Science 257: 967-971.

Lin, R., S. Thompson, and J.R. Priess. 1995. pop-1 encodes an HMG box protein required for the specification of a mesoderm precursor in early C. elegans embryos. Cell 83: 599609.

Liu, C.-Y., A. Flesken-Nikitin, S. Lu, Y. Zeng, and W.-H. Lee. 1996. Inactivation of the mouse Brca-1 gene leads to failure of the egg cylinder in early postimplantation development. Gene \& Dev. 10: 1835-1843.

Liu, D., J.C. Chang, P. Moi, W. Liu, Y.W. Kan, and P.T. Curtin. 1992 . Dissection of the enhancer activity of $\beta$-globin 5 ' DNase I-hypersensitive site 2 in transgenic mice. Proc. Natl. Acad Sci. 89: 3899-3903.

Luna, L., O. Johnsen, A.H. Skartlien, F. Pedeutour, C. TurcCarel, H. Prydz, and A.-B. Kolsto. 1994. Molecular cloning of a putative novel human bZIP transcription factor on chromosome 17q22. Genomics 22: 553-562. 
Martin, D.I.K., S. Fiering, and M. Groudine. 1996. Regulation of $\beta$-globin gene expression: Straightening out the locus. Curr. Opin. Genet. Dev. 9: 488-495.

Matsuo, I., S. Kuratani, C. Kimura, N. Takeda, and S. Aizawa. 1995. Mouse Otx2 functions in the formation and patterning of rostral head. Genes \& Dev. 9: 2646-2658.

McKie, J., K. Johnstone, M.-G. Mattei, and P. Scambler. 1995. Cloning and mapping of murine Nfe2L1. Genomics 25: 716 719.

Medvinksy, A. and E. Dzierzak. 1996. Definitive hematopoiesis is autonomously initiated by the AGM region. Cell 86: 879 906.

Medvinsky, A.L., N.L. Samoylina, A.M. Muller, and E.A. Dzierzak. 1993. An early pre-liver intraembryonic source of CFU-S in the developing mouse. Nature 364: 64-67.

Mishina, Y., A. Suzuki, N. Ueno, and R.R. Behringer. 1995. BMPR encodes a type I bone morphogenetic protein receptor that is essential for gastrulation during mouse embryogenesis. Genes \& Dev. 9: 3027-3037.

Mohler, J., K. Vani, S. Leung, and A. Epstein. 1991. Segmentally restricted, cephalic expression of leucine zipper gene during Drosophila embryogenesis. Mech. Dev. 34: 3-10.

Mohler, J., J.W. Mahaffey, E. Deutsch, and K. Vani. 1995. Control of Drosophila head seqment identity by the bZIP homeotic gene cnc. Development 121: 237-247.

Moi, P. and Y.W. Kan. 1990. Synergistic enhancement of globin gene expression by activator protein-1-like proteins. Proc. Natl. Acad. Sci. 87: 9000-9004.

Moi, P., K. Chan, I. Asunis, A. Cao, and Y.W. Kan. 1994. Isolation of NF-E2-related factor (Nrf2), an NF-E2-like basic leucine zipper transcriptional activator that binds to the tandem NF-E2/AP1 repeat of the $\beta$-globin locus control region. Proc. Nat1. Acad. Sci. 91: 9926-9930.

Mortensen, R.M., D.A. Conner, S. Chao, A.A.T. Geisterfer-Lowrance, and J.G. Seidman. 1992. Production of homozygous mutant ES cells with a single targeting construct. Mol. Cell. Biol. 12: 2391-2395.

Nagy, A. and J. Rossant. 1993. Production of completely ES cell-derived fetuses. In Gene targeting, a practical approach, 1st edition. (ed. Alexandra L. Joyner), pp. 107-146. IRL Press, New York, NY.

Nasir, J., S.B. Floresco, J.R. O'Kusky, V.M. Diewert, J.M. Richman, J. Zeisler, A. Borowski, J.D. Marth, A.G. Phillips, and M.R. Hayden. 1995. Targeted distribution of the Huntington's disease gene results in embryonic lethality and behavioral and morphological changes in heterozygotes. Cell 81: 811-823.

Ney, P.A., B.P. Sorrentino, K.T. McDonagh, and A.W. Nienhuis. 1990. Tandem AP-1-binding sites within the human $\beta$-globin dominant control region function as an inducible enhancer in erythroid cells. Genes \& Dev. 4: 993-1006.

Orkin, S.H. 1990. Globin gene regulation and switching: Circa 1990. Cell 63: 665-672.

Pearse, A.G.E. 1985. Pigments and pigment precursors. Churchill Livingstone, New York, NY.

Pollock, R. and R. Treisman. 1990. A sensitive method for the determination of protein-DNA-binding specificities. Nucleic Acids Res. 18: 6197-6204.

Robertson, E.J. 1987. Embryo-derived stem cell lines. In Teratocarcinomas and embryonic stem cells: A practical approach, 1st edition. (ed. Elizabeth J. Robertson), pp. 71-112. IRL Press, Oxford, UK.

Rossant, J. and K.M. Vijh. 1981. In vivo and in vitro development of mouse embryos homozygous for the embryonic lethal velvet coat (Ve) mutation. J. Embryol. Exp. Morphol. 66: 43-55.
Schumacher, A., C. Faust, and T. Magnuson. 1996. Positional cloning of a global regulator of anterior-posterior patterning in mice. Nature 383: 250-253.

Shawlot, W. and R.R. Behringer. 1995. Requirement for Lim 1 in head-organizer function. Nature 374: 425-430.

Shivdasani, R.A. and S.H. Orkin. 1995. Erythropoiesis and globin gene expression in mice lacking the transcription factor NF-E2. Proc. Nat1. Acad. Sci. 92: 8690-8694.

Shivdasani, R.A., M.F. Rosenblatt, D. Zucker-Franklin, C.W. Jackson, P. Hunt, C.J.M. Saris, and S.H. Orkin. 1995. Transcription factor NF-E2 is required for platelet formation independent of the actions of thrombopoietin/MGDF in megakaryocyte development. Cell 81: 695-704.

Sive, H.L. and T. St. John. 1988. A simple subractive hybridization technique employing photoactivatable biotin and phenol extraction. Nucleic Acids Res. 16: 10937.

St. Jacques, B. and A.P. McMahon. 1996. Early mouse development: Lessons from gene targeting. Curr. Opin. Genet. Dev. 6: $439-444$.

Stamatoyannopoulos, G. 1991. Human hemoglobin switching. Science 252: 383.

Stamatoyannopoulos, J.A., A. Goodwin, T. Joyce, and C.H. Lowrey. 1995. NF-E2 and GATA binding motifs are required for the formation of DNase I hypersensitive site 4 of the human beta-globin locus control region. EMBO T. 14: 106-116.

Stephens, L.E., A.E. Sutherland, I.V. Klimanskaya, A. Andrieuz, J. Meneses, R.A. Pederson, and C.H. Damsky. 1995. Deletion of $\beta 1$ integrins in mice results in inner cell mass failure and peri-implantation lethality. Genes \& Dev. 9: 1883-1895.

Stevens, A. 1990. Pigments and minerals. In Theory and practice of histological techniques, 3rd ed. (ed. John D. Bancroft and Alan Stevens), pp. 245-268. Churchill Livingstone, Avon, UK.

Swiatek, P.J., C.E. Lindsell, F.F. del Amo, G. Weinmaster, and T. Gridley. 1994. Notch1 is essential for postimplantation development in mice. Genes \& Dev. 8: 707-719.

Szostak, J.W. 1992. In vitro genetics. Trends Biochem. Sci. 17: 89-93.

Talbot, D. and F. Grosveld. 1991. The 5'HS2 of the globin locus control region enhances transcription through the interaction of a multimeric complex binding at two functionally distinct NF-E2 binding sites. EMBO J. 10: 1391-1398.

Talbot, D., S. Philipsen, P. Fraser, and F. Grosveld. 1990. Detailed analysis of the site 3 region of the human $\beta$-globin dominant control region. EMBO J. 9: 2169-2178.

Townes, T.M. and R.R. Behringer. 1990. Human globin locus activation region (LAR): Role in temporal control. Trends Genet. 6: 219-223.

Warner, C.M., T.E. Meyer, D. Balinsky, and C.J. Briggs. 1985. Variations in the amount of glucose phosphate isomerase in lymphocytes and erythrocytes from A/J and C57BL/6J mice. Biochem. Genet. 23: 815-825.

Weinstein, D.C., A.R.L. Altaba, W.S. Chen, P. Hoodless, V.R. Prezoiso, T.M. Jessell, and J.E. Darnell, Jr. 1994. The wingedhelix transcription factor HNF-3 $\beta$ is required for notochord development in the mouse embryo. Cell 78: 575-588.

Wiles, M.V. 1993. Embryonic stem cell differentiation in vitro. Methods Enzymol. 225: 900-918.

Wilkinson, D.G., S. Bhatt, and B.G. Herrmann. 1990. Expression pattern of the mouse $\mathrm{T}$ gene and its role in mesoderm formation. Nature 343: 657-659.

Winnier, G., M. Blessing, P.A. Labosky, and B.L.M. Hogan. 1995. Bone morphogenetic protein-4 is required for mesodermal formation and patterning in the mouse. Genes \& Dev. 9: 2105-2116.

Wright, W.E. and W.D. Funk. 1993. CASTing for multicompo- 
Farmer et al.

nent DNA-binding complexes. Trends Biochem. Sci. 18: 7780.

Yamaguchi, T.P., K. Harpal, M. Henkemeyer, and J. Rossant. 1994. Fgfr-1 is required for embryonic growth and mesodermal patterning during mouse gastrulation. Genes \& Dev. 8: 3032-3044.

Zeitlin, S., J.-P. Liu, D.L. Chapman, V.E. Papaioannou, and A. Efstratiadis. 1995. Increased apoptosis and early embryonic lethality in mice nullizygous for the Huntington's disease gene homologue. Nature Genet. 11: 155-163.

Zhao, G.-Q. and B.L.M. Hogan. 1996. Evidence that mouse $\mathrm{Bmp} 8 \mathrm{a}(\mathrm{Op} 2)$ and $\mathrm{Bmp} 8 \mathrm{~b}$ are duplicated genes that play a role in spermatogenesis and placental development. Mech. Dev. 57: 159-168.

Zhao, G.-Q., K. Deng, P.A. Labosky, L. Liaw, and B.L.M. Hogan. 1996. The gene encoding bone morphogenetic protein $8 \mathrm{~B}$ is required for the initiation and maintenance of spermatogenesis in the mouse. Gene \& Dev. 10: 1657-1669.

Zhou, X., H. Sasaki, L. Lowe, B.L.M. Hogan, and M.R. Keuhn. 1993. Nodal is a novel TGF $\beta$-like gene expressed in the mouse node during gastrulation. Nature 361: 543-547. 


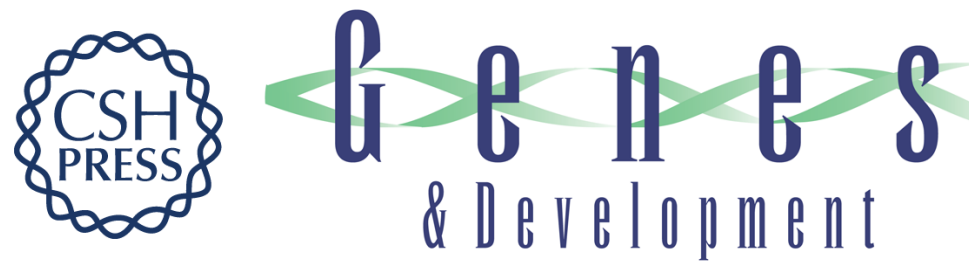

\section{The bZIP transcription factor LCR-F1 is essential for mesoderm formation in mouse development.}

S C Farmer, C W Sun, G E Winnier, et al.

Genes Dev. 1997, 11:

Access the most recent version at doi:10.1101/gad.11.6.786

References This article cites 90 articles, 35 of which can be accessed free at:

http://genesdev.cshlp.org/content/11/6/786.full.html\#ref-list-1

License

Email Alerting

Service right corner of the article or click here.

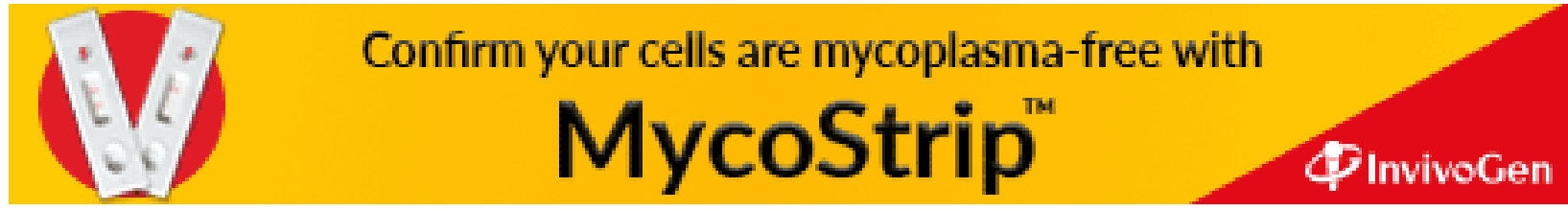

